\title{
Natural and improved natural pastures on the reproductive performance of first-calf beef cows
}

\author{
Soraya Tanure ${ }^{1}$, Bernardo Augusto Albornoz Pötter ${ }^{1}$, José Fernando Piva Lobato ${ }^{1}$ \\ ${ }^{1}$ Universidade Federal do Rio Grande do Sul, Faculdade de Agronomia, Departamento de Zootecnia.
}

ABSTRACT - This work evaluated the reproductive performance of first-calf cows at three years of age, submitted or not to protein supplementation at yearling on natural pastures. After calving, cows were managed on natural or improved pastures. The feeding managements were the following: on natural pastures as yearlings and during pregnancy, post-calving period and breeding season; on natural pastures with protein supplement as yearlings and only natural pasture during pregnancy, post-calving and breeding season; on natural pastures as yearlings and during pregnancy and on improved natural pastures (Lolium multiflorum L., Trifolium repens cv. Yi and Lotus corniculatus cv. São Gabriel) during the post-calving period and breeding season; on natural pastures with protein supplement at yearling, on natural pastures during pregnancy, and on improved natural pasture during post-calving period and breeding season. Cows did not differ on body weight, but from calving to the beginning of breeding season, cows on improved natural pastures presented higher weight gain than those on natural pastures $(0.203 \mathrm{vs} .0 .109 \mathrm{~kg} / \mathrm{day})$. Cows in post-calving on natural pastures lost 1.0 point of body condition score during mating, determinant of the lowest pregnancy rate and later conception in relation to cows on improved natural pasture. Pregnant cows presented higher body weight $(440 \mathrm{vs} .413 \mathrm{~kg})$ and body condition score ( 4.14 vs. 3.66 points) than open cows at the end of the breeding season.

Key Words: body condition score,body weight variation, Braford, post-calving, pregnancy rate

\section{Pastagens naturais e melhoradas no desempenho reprodutivo de vacas de corte primíparas}

RESUMO - O trabalho avaliou o desempenho reprodutivo de vacas primíparas aos três anos de idade, submetidas previamente ou não à suplementação protéica no sobreano sobre pastagens naturais. Após o parto, foram manejadas em pastagens naturais ou naturais melhoradas. Os manejos alimentares foram: em pastagem natural na recria e nos períodos de gestação, pós-parto e reprodutivo; em pastagem natural com suplemento protéico na recria e somente pastagem natural durante os períodos de gestação, pós-parto e reprodutivo; em pastagem natural durante a recria e período de gestação, em pastagem natural melhorada (Lolium multiflorum L., Trifolium repens cv. Yi e Lotus corniculatus L. cv. São Gabriel) nos períodos pós-parto e reprodutivo; em pastagem natural com suplemento protéico na recria, em pastagem natural no período de gestação e em pastagem natural melhorada nos períodos pós-parto e reprodutivo. As vacas não diferiram em peso corporal, porém do parto ao início do acasalamento vacas em pastagem natural melhorada tiveram maiores ganhos de peso do que as vacas mantidas em pastagem natural (0,230 vs $0,109 \mathrm{~kg} / \mathrm{dia})$. Vacas no pós-parto em pastagens naturais perderam 1,0 ponto de condição corporal durante o acasalamento, determinante da menor taxa de prenhez e de concepções mais tardias em relação às vacas em pastagem natural melhorada. Vacas que conceberam apresentaram maior peso (440 vs $413 \mathrm{~kg}$ ) e condição corporal (4,14 vs 3,66 pontos) no final do acasalamento do que as vacas não prenhes.

Palavras-chave: Braford, condição corporal, pós-parto, taxa de prenhez, variação de peso corporal

\section{Introduction}

The reproductive function of breeding herds is influenced by nutrition and genotype, as well as management, and forage allowance and quality are essential for the reproductive performance of beef cattle (Nicol \& Nicoll, 1987; Pötter \& Lobato, 2004), and therefore, for the productivity of beef cattle systems (Pötter et al., 1998; Beretta et al., 2001).

Studies carried out with first-calf cows show that reproductive indexes are associated to stocking rate, forage allowance, variation in calving weight at the end of the breeding season, and body weight and body condition score at the beginning of the breeding season 
(Gottschall \& Lobato 1996; Quadros \& Lobato, 1996; Fagundes et al., 2003; Vieira et al., 2005). Cachapuz et al. (1990), Lobato et al. (1998a,b) and Lobato et al. (2010) observed higher pregnancy rates in first-calf cows managed on improved natural pastures as compared to those maintained on natural pastures.

In breeding herds, it is more difficult to obtain adequate reproductive responses in first-calf cows due to calving stress (Spitzer, 1986) and to the effects of growth (Freetly, 1999) combined to first lactation, which increase nutritional requirements (Spitzer et al., 1995). These requirements may be supplied by adequate forage allowance when animals graze on natural or improved natural pastures (Lobato et al., 1998b; Pötter \& Lobato, 2004).

According to Lobato et al. (1998b), post-calving nutritional levels are conditioned by pre-calving nutritional levels. When pre-calving nutritional levels are not able to supply the requirements, which occurs for a long period of time, resulting in weight loss, post-calving nutritional level will determine if the cow will conceive or not (Spitzer et al., 1995). On the other hand, when nutritional requirements are supplied during the pre-calving period, post-calving nutritional levels will determine the interval between calving and first estrus (Wiltbank et al., 1962). Rosado Júnior \& Lobato (2009) identified macroprocesses in a Brazilian beef production system in which forage allowances and feeds determine the success of the calf production process.

The hypothesis of the present study is that first-calf cows supplemented with proteinated salt from yearlings until first breeding (24 to 26 months of age) would present higher body weight and better body condition score at calving and in the post-calving period when compared to those maintained exclusively on natural pastures. Therefore, the reproductive performance of first-calf beef cows submitted to different feeding strategies as yearlings and post-calving managed in grazing systems in the western frontier of the state of Rio Grande do Sul, Brazil.

\section{Material and Methods}

The experiment was carried out on the farm Agropecuária Caty, located in the the municipality of Quaraí, which is located in the region of Campanha, in the western frontier of the state of Rio Grande do Sul, Brazil, at $30^{\circ} 262043 \mathrm{~S}$ and $56^{\circ} 012153 \mathrm{~W}$. According to Köppen's classification (Moreno, 1961), the climate is Cfa 2, which is mesothermal subtropical.

Precipitation data were obtained at Agropecuária Caty (Table 1) and temperature and air relative humidity data of the municipality of Quaraí were supplied by Fundação Estadual de Pesquisa Agropecuária (FEPAGRO, 2008).

The relief consists of hills and valleys, with shallow and moderately acid soils on the hills. The soil is classified as Vertisol, poorly drained, black, very plastic with high content of clay, and formed from basalt (EMBRAPA, 1999).

A total of 77 pregnant Braford heifers, at 24 to 26 months of age, were evaluated from April 12 2007 (pregnancy diagnosis) to March $18^{\text {th }} 2008$. Average body weight (BW) at the beginning of the experiment was $454 \mathrm{~kg}$. Initial body condition score (BCS) was 4.5 in the scale of Lowman et al. (1973), where 1 corresponds to a thin animal and 5 to a fat animal. From the beginning of the experiment until calving, heifers were maintained on natural pastures, and were randomly distributed as follows:

$\mathrm{NP}=17$ heifers managed on natural pastures as yearlings, during pregnancy, and during the breeding

Table 1 - Precipitation, maximum and minimum average temperatures, and air relative humidity during the experimental period

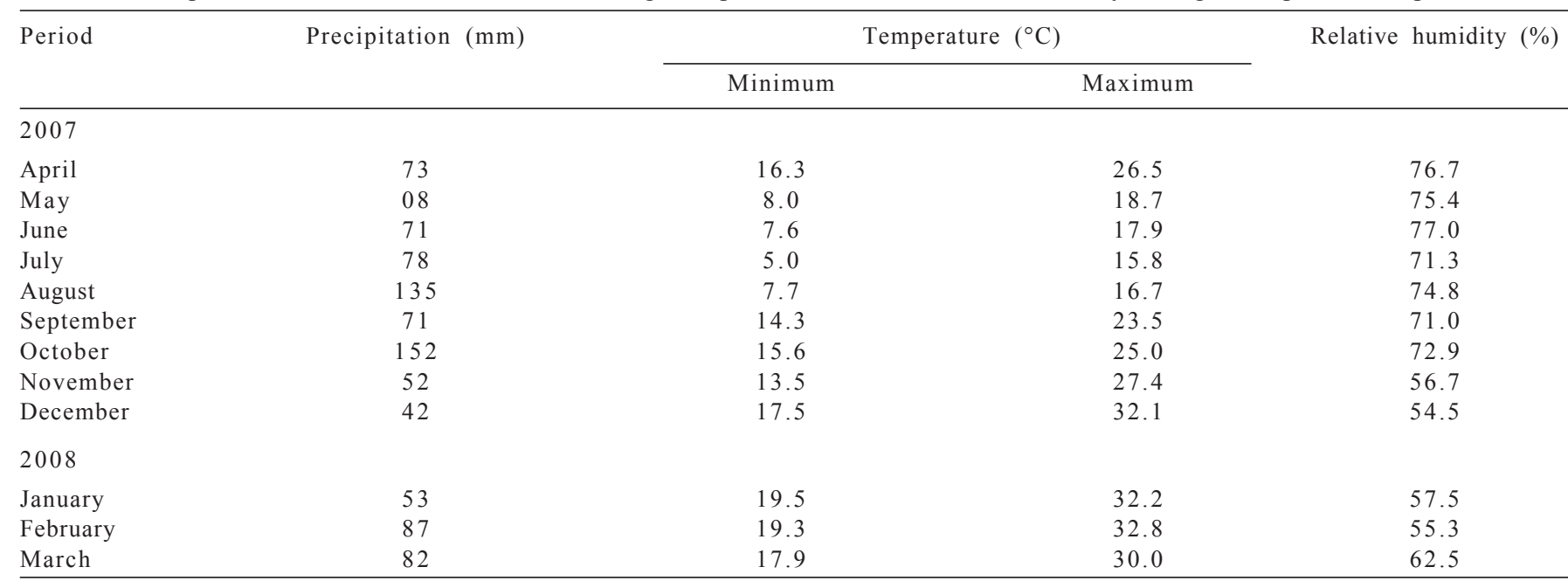


season as first-calf cows, at a stocking rate of 0.71 animal unit (AU) per hectare (1 $\mathrm{AU}=450 \mathrm{~kg}$ body weight);

$\mathrm{NPSu}=21$ heifers managed as yearlings on natural pastures and with access to a protein supplement (proteinated salt) at a level of $0.1 \%$ body weight for 120 days before the first breeding, and exclusively on natural pastures during gestation and the breeding season as first-calf cows, at a stocking rate of $0.71 \mathrm{AU} / \mathrm{ha}$;

INP $=19$ heifers managed as yearlings on natural pastures at a stocking rate of $0.71 \mathrm{AU} / \mathrm{ha}$ and on improved natural pastures after calving until the end of the breeding season, from September 2007 to January 2008, at a stocking rate of $1 \mathrm{AU} / \mathrm{ha}$;

$\mathrm{INPSu}=20$ heifers managed on natural pastures and access to a protein supplement as yearlings until calving, as the heifers in the NPSu group, but after moved to improved natural pastures post-calving where they remained until the end of the breeding season, from September 2007 to January 2008, at a stocking rate of $1 \mathrm{AU} / \mathrm{ha}$.

The natural pastures in that region predominantly consist of summer-cycle species (Andropogon lateralis, Desmodium incanum, Paspalum dilatatum, Paspalum notatum and Trifolium polimorphum). The improved natural pastures, in addition to the aforementioned species, also included winter/spring-cycle species: annual ryegrass (Lolium multiflorum L., cv. IEb-284), white clover (Trifolium repens, cv. Yi), and birdsfoot trefoil (Lotus corniculatus, cv. São Gabriel). Paddock areas were 70 and 42 hectares, for natural pastures and improved natural pastures, respectively.

Forage mass in the paddocks with natural pastures and improved natural pastures was evaluated every 28 days using the double-sampling method (Haydock \& Shaw, 1975). At each sampling, 60 visual random assessments were made, and scored in a scale from 1 (low allowance) to 5 (high allowance) according to standards previously defined in each paddock, also scored from 1 to 5 . Average visual score in each paddock was adjusted to dry forage mass using the regression established between the mass of the standards and their visual estimates.

Forage samples were dried in an oven at $60^{\circ} \mathrm{C}$ until constant weight to determine dry matter content (DM) and subsequently ground and analyzed at the Laboratório de Nutrição Animal to determine crude protein (CP), neutral detergent fiber (NDF), and acid detergent fiber (ADF) contents (AOAC, 1975).

Heifers were monthly weighed after pregnancy diagnosis on April $12^{\text {th }} 2007$, when they were approximately at 30 months of age. During the calving season (spring of 2007), cows and calves were weighed up to 24 hours post- calving, and continued to be weighed, after 12-hours fasting, until the end of the breeding season, on $30^{\text {th }}$ January2008. BCS was assessed always when the animals were weighed (Lowman et al., 1973).

Stocking rates were adjusted after cows were weighed in order to maintain the stocking rates defined in each treatment. Pasture allowance was calculated by dividing forrage mass by 28 days and the result was multiplied by 100 and divided stocking rate.

Endo and ectoparasites were controlled according to the health management calendar of the farm. Control was made by drenching with ivermectin at $1 \%$ post-calving and endoparasites were controlled according to infestation load.

Breeding season duration was 70 days $\left(20^{\text {th }}\right.$ November 2007 to $30^{\text {th }}$ January2008). Sires previously approved by andrological examination were used at a $2 \%$. Pregnancy was diagnosed using ultrasound examination with a $5-\mathrm{MHz}$ linear transrectal probe on February $7^{\text {th }}$ and March $18^{\text {th }} 2008$ to follow up pregnancy rate during the breeding season.

A completely randomized experimental design was used, consisting of four feeding management practices, and animals were used as replicates. The collected data were submitted to analysis of variance, and differences among means were tested by the $\mathrm{F}$ test according to the following general model:

$$
Y i j=\mu+T i+A_{j}(T)_{i}+\varepsilon i j
$$

where: $\mathrm{Yij}=$ dependent variables; $\mu=$ mean of all observations; $\mathrm{Ti}=$ effect of the $\mathrm{i}^{\text {th }}$ feeding management practice; $A_{j}(T)_{i}=$ effect of the $j^{\text {th }}$ animal within the $i^{\text {th }}$ feeding management practice (error A); $\varepsilon i j=$ residual error (error B).

Analyses were determined by the Generalized Linear Model (GLM) and differences among means were complemented by Tukey test at 5\%. Data relative to pregnancy rate during the breeding season were analyzed by the Chi-Square test. Statgraphics 4.1 (1999) software package was used.

\section{Results and Discussion}

The mean forage mass (FM) of natural pastures for the four evaluated periods (initial and intermediate gestation period, pre-calving period, and breeding season) was $2771 \mathrm{~kg} / \mathrm{ha} \mathrm{DM}$ (Table 2). The adjustment of stocking rate in $320 \mathrm{~kg} / \mathrm{ha}$ throughout the experiment allowed maintaining a pasture allowance of $35 \mathrm{~kg} \mathrm{DM} / 100 \mathrm{~kg} \mathrm{BW}$, which is according to the recommendations to promote selective grazing. According to Gibb \& Treacher (1976), 
Table 2 - Quantitative and qualitative parameters of the pastures used during the gestation and post-calving periods

\begin{tabular}{|c|c|c|c|c|c|c|c|}
\hline \multirow[t]{4}{*}{ Parameter } & \multicolumn{5}{|c|}{ Natural pastures } & \multicolumn{2}{|c|}{ Improved natural pastures } \\
\hline & Beginning pregnancy & \multirow{2}{*}{$\frac{\text { Middle pregnancy }}{\text { June }}$} & \multirow{2}{*}{$\frac{\text { Pre-calving }}{\text { August }}$} & \multicolumn{2}{|c|}{ Breeding season } & \multicolumn{2}{|c|}{ Breeding season } \\
\hline & April & & & March & February & December & February \\
\hline & $12^{\text {th }} 2007$ & $20^{\text {th }} 2007$ & $17^{\text {th }} 2007$ & $3^{\text {rd }} 2007$ & $7^{\text {th }} 2008$ & $3^{\text {rd }} 2007$ & $7^{\text {th }} 2008$ \\
\hline Forage mass $(\mathrm{kg} / \mathrm{ha})$ & 3835 & 2920 & 2261 & 2482 & 2360 & 3289 & 2985 \\
\hline Crude protein $(\%)$ & 8.7 & 8.6 & 6.4 & 5.5 & 5.7 & 7.6 & 5.1 \\
\hline Neutral detergent fiber $(\%)$ & 75.03 & 66.91 & 73.34 & 80.40 & 86.72 & 64.48 & 84.89 \\
\hline Acid detergent fiber $(\%)$ & 38.06 & 34.36 & 48.93 & 47.76 & 51.29 & 39.27 & 49.82 \\
\hline
\end{tabular}

pasture allowance should be at least three times higher than the estimated intake in order not to constrain animal performance. The forage intake of beef heifers is estimated in $2.5 \% \mathrm{BW}(\mathrm{NRC}, 1996)$.

The improved natural pastures were managed at a stocking rate of $450 \mathrm{~kg} / \mathrm{ha}$ as a function of its average quantitative and qualitative behavior and of the climate conditions expected for the period. Although the low rainfall occurring in September $(71 \mathrm{~mm})$ and its irregular distribution in October (152 mm; Table 1) hindered the development of some species, the high pasture allowance allowed the maintenance of the stocking rate, preserving the botanical composition of the pastures and maintaining cow body weight. Improved natural pastures areas allow improving feed conversion ratio in the spring due to their higher production and quality (Nicol \& Nicoll, 1987; Cachapuz etal., 1990; Pötter \& Lobato, 2004).

The quality of the available pastures, particularly their high NDF and ADF values, did not limit animal performance. According to Mertens (1987), forage intake potential of a ruminant is $1.2 \%$ of its BW in NDF. In the present study, considering an average initial heifer BW of $454 \mathrm{~kg}$ on April $12^{\text {th }} 2007$, heifer intake should be, on average, $11 \mathrm{~kg} \mathrm{DM} /$ day or $5.4 \mathrm{~kg} \mathrm{NDF}$. However, forage type, the interaction with other factors of intake regulation, and diet selection may affect the intake capacity of cows (Van Soest, 1994), making pasture intake estimation, and consequently, animal performance prediction highly subjective in this situation.

Except for the natural pastures sampled on December $3^{\text {rd }} 2007$ and February $7^{\text {th }} 2008$, CP content of both natural and improved pastures was higher than the $6-7 \%$ suggested by Mertens (1987) as limiting to the digestion of the fiber fraction of forages, resulting in lower production of volatile fatty acids, and therefore, worse animal performance. In natural pastures, forrage mass (3835 kg/ha DM) and CP content $(8.7 \%)$ in the beginning of pregnancy, as well as the values obtained (Table 2) until the end of the breeding season, suggest sufficient forage intake by the cows, resulting in adequate weight gain and body conditions score throughout gestation (Table 3). Calving weight is highly dependent on forage availability and quality before calving (Spitzer et al., 1995; Lobato etal., 1998a), and determines the reproductive performance in the next breeding season (Wiltbank et al., 1962).

There were no differences in body weight in the beginning of pregnancy, but body condition scores, which were considered very good for this stage, were higher for cows submitted to the natural pastures as yearlings and improved pastures post-calving and natural pastures with protein supplementation as yearlings and improced pastures

Table 3 - Body weight $(\mathrm{kg})$ and body condition score of heifers evaluated during pregnancy diagnosis and at calving, and body weight of first-calf cows at the beginning of the breeding season

\begin{tabular}{|c|c|c|c|c|c|}
\hline Parameter & $\begin{array}{l}\text { Natural } \\
\text { pastures }\end{array}$ & $\begin{array}{l}\text { Natural pastures } \\
\text { with protein } \\
\text { supplementation } \\
\text { as yearlings }\end{array}$ & $\begin{array}{c}\text { Natural pastures as yearlings } \\
\text { and improved } \\
\text { pastures } \\
\text { post-calving }\end{array}$ & $\begin{array}{l}\text { Natural pastures with } \\
\text { protein supplementation } \\
\text { as yearlings and improved } \\
\text { pastures post-calving }\end{array}$ & Mean \\
\hline \multicolumn{6}{|l|}{ Pregnancy diagnosis } \\
\hline Body weight & 443 & 463 & 456 & 454 & 454 \\
\hline $\begin{array}{l}\text { Body condition score } \\
\text { Calving }\end{array}$ & $4.78 b$ & $4.88 \mathrm{ab}$ & $4.90 \mathrm{ab}$ & $4.95 \mathrm{a}$ & 4.87 \\
\hline Body weight & $422 \mathrm{ab}$ & $450 \mathrm{a}$ & $417 b$ & $421 \mathrm{~b}$ & 427.5 \\
\hline Body condition score & $3.77 \mathrm{a}$ & $3.67 \mathrm{a}$ & $3.41 \mathrm{ab}$ & $3.23 b$ & 3.52 \\
\hline $\begin{array}{l}\text { Body weight beginning } \\
\text { of the breeding season }\end{array}$ & 451 & 471 & 455 & 459 & 459 \\
\hline Daily weight gain ${ }_{C-B S}$ & $0.131 \mathrm{~b}$ & $0.087 \mathrm{c}$ & $0.258 \mathrm{a}$ & $0.203 \mathrm{ab}$ & 0.169 \\
\hline
\end{tabular}

a, $b$ Means followed by different letters in the same row differ $(\mathrm{P}<0.05)$ by Tukey test.

$\mathrm{DWG}_{\mathrm{C}-\mathrm{BS}}$ - Daily weight gain ( $\left.\mathrm{kg} / \mathrm{cow} / \mathrm{day}\right)$ from calving to the beginning of the breeding season. 
post-calving treatments $(\mathrm{P}<0.05)$. However, body weight and body condition score results changed until the end of pregnancy. At calving, NPSu cows presented the highest body weight $(\mathrm{P}<0.05)$ and the INPSu group, the lowest body condition score $(\mathrm{P}<0.05)$. In addition to the variation among individuals as to nutritional requirements during pregnancy (NRC, 1996) that may occur within the same herd, the weight and body condition score losses observed at calving are associated to calf weight and fetal membranes (Sptizer, 1986). Approximately $40 \%$ of cow weight loss at calving corresponds to fetal liquids and to the placenta, and the remaining 60\% to the calf (Sptizer, 1986). In the present study, considering an average calf birth weight of $32 \mathrm{~kg}$, according to Sptizer (1986), it is estimated that pre-calving heifers weighed, in average, 470-480 kg of BW, which indicates weight gain during pregnancy. This was due to the management of heifers on natural pastures with high pasture allowance (33 kg DM/100 kg BW), allowing diet selection, thereby justifying the average body weights and body condition scores determined immediately after the first calving of cows that were still in the growing phase.

The pre-calving body weight of 470-480 $\mathrm{kg}$ and the body weight and body condition score determined up to 24 -h post-calving indicate that there were no losses in these parameters during the fall/winter period. The results of the present study emphasize the benefits of maintaining high availability of natural pastures and high BCS during fall/winter, particularly from early May to late August, to avoid significant cow weight loss (Moraes et al., 1995). In the case of pregnant heifers, gaining of weight during pregnancy and post-calving periods, before the subsequent breeding season, allow them to continue their body development (Freetly, 1999), which is related to reproductive performance (Lobato et al., 1998b).

Although no residual effect of the management practices applied to the yearling heifers in the previous year were observed during pregnancy, their good development until the beginning of the first breeding season contributed to the evolution of weights until calving.

The observed calving weights (Table 3 ) are higher than those obtained for first-calf cows derived from Zebu $\times$ British cross in other studies (Barcellos \& Lobato, 1997; Lobato et al., 1998b; Pötter \& Lobato, 2004; Vaz et al., 2010). Barcellos \& Lobato (1997) found post-calving weights of 372,411 , and $398 \mathrm{~kg}$ for first-calfHereford, $1 / 2$ and $1 / 4$ Braford cows, respectively.

Literature suggest that mature cows with $480-520 \mathrm{~kg}$ BW should reach $380-420 \mathrm{~kg} \mathrm{BW}$ at three years of age, which correspond to $80 \%$ of their mature weight, in order to obtain good reproductive performance (Rovira, 1996). In the present study, considering a mature cow BW of $500 \mathrm{~kg}$, average post-calving weight corresponded to $85.5 \%$ of mature BW, which is similar to the $86 \%$ observed by Pötter \& Lobato (2004) in first-calf cows in the same herd. Lobato et al. (1998b) obtained $370 \mathrm{~kg}$ post-calving BW in first-calf cows maintained exclusively on natural pastures and $410 \mathrm{~kg}$ for those maintained on improved pastures.

Body condition scores at calving of cows submitted to the natural pasture and natural pastures with protein supplementation as yearlings management practices were higher $(\mathrm{P}<0.05)$ than those of cows submitted to the other treatments. Although all animals were maintained on the same natural pastures from pregnancy diagnosis to calving, some animals may have selected the diet better. According to Pinto et al. (2007), high pasture heterogeneity, for example, natural pastures of Rio Grande do Sul (Boldrini, 1997), may promote high selectivity by the cattle. The natural pastures of the experimental area included good-quality species (Desmodium incanum, Paspalum dilatatum, Paspalum notatum, and Trifolium polimorphum), and other species with high forage potential (Andropogon lateralis), contributing to the observed animal performance.

The loss of body condition score observed in all animals, regardless to the feeding management, from the beginning of pregnancy (April 12 ${ }^{\text {th }}$ 2007) to calving was, on average, 1.35 points (Table 3 ). Moraes \& Lobato (1993), studying first-calf Hereford cows at 42 months of age during the preand post-calving period on natural pastures, registered a loss of 0.37 points in body condition score. Herd \& Sprott (1996) recommends a body condition score at calving equal or higher than 3.0 in order to obtain good reproductive efficiency during the next breeding season. In the present study, average body condition score was 3.52 , which is higher than the minimum score for mature cows, according to Dziuk \& Bellows (1983), and similar to the 3.5 points that are considered adequate by DeRouen et al. (1994) for first-calf cows.

Post-calving average weight gain was positively influenced by the use of improved pastures, presenting an average of 0.230 vs. $0.109 \mathrm{~kg} /$ day on natural pastures (Table 3), which contributed to the recovery of BCS and to the better reproductive performance $(\mathrm{P}<0.05)$ obtained in the INP and INPSu treatments (Table 4). The lower weight gain presented by NPSu cows was due to their calving weight gain, which was $28 \mathrm{~kg}$ higher.

Cachapuz et al. (1990) observed higher daily weight gain $(\mathrm{P}<0.01)$ during the post-calving period in first-calf cows maintained on improved pastures as compared to those grazing only natural pastures. Lobato et al. (2010) 
obtained an average gain of $0.457 \mathrm{~kg}$ /day in first-calf cows managed on improved pastures, which was significantly different $(\mathrm{P}<0.05)$ from those managed on natural pastures, which maintained body weight or lost up to $0.219 \mathrm{~kg} / \mathrm{day}$.

Body weight and body condition score at the beginning of the breeding season (PIA; CCI) were not different $(\mathrm{P}>0.05)$ among treatments (Table 4). However, animals lost weight during that season, with higher weight losses in natural pasture e natural pastures with protein supplementation as yearlings cows, i.e., those maintained on natural pastures, determining 1.0 point lower body condition score at the end of the period relative to the initial body condition score (4.79 vs. 3.77 ).

Despite the availability of forage mass, the qualitative values of natural pastures, particularly NDF $(80.4 \%$; Table 2 ), may have limited forage intake and resulted in weight loss, which determined the lower pregnancy rates (Table 4 ).

The higher body weights at the end of the breeding season (PFA) and the lower body weight and body condition score losses ( 0.56 and 0.34 points) observed during this period with the INP and INPSu managements, respectively, are due to the better nutritional supply of the improved pastures during the post-calving period. The average weights of 440 and $449 \mathrm{~kg}$ at the end of the breeding season were similar to those obtained by Lobato et al. (2010) with first-calf Brangus cows and higher than the $415-\mathrm{kg}$ described by Pötter \& Lobato (2004), with first-calf cows from the same herd and location maintained on improved pastures for 80 days post-calving, and the $412 \mathrm{~kg}$ determined by Lobato et al. (1998a) with improved pastures during pre- and post-calving.

Body weights of 412 and $426 \mathrm{~kg}$ at the end of the breeding season and the pregnancy rates of 76.5 and $71.4 \%$ obtained in the natural pasture e natural pastures with protein supplementation as yearlings treatments, respectively, indicate that the mature weight of this cow herd is slightly higher than the $500 \mathrm{~kg}$ previously considered. Therefore, higher body weights would be needed at the end of the breeding season. However, according to Rovira (1996), first-calf cows should achieve $88 \%$ of their mature weight at the end of the breeding season. Cows under INP and INPSu management practices weighed in average 440 and $449 \mathrm{~kg}$, that is, they reached 88 and $90 \%$ of the mature weight of $500-\mathrm{kg}$ cows, and presented $94.7 \%$ and $95.0 \%$ pregnancy rates, respectively. The average body weights of 412 and $426 \mathrm{~kg}$ obtained at the end of the breeding season by cows in groups INP and INPSu, respectively, corresponded only to $82 \%$ and $85 \%$ of $500-\mathrm{kg}$ mature weight. Lobato et al. (2010), working with first-calf Brangus cows with $416 \mathrm{~kg}$ average body weight and 3.5 body condition score at the end of the breeding season, obtained $64.3 \%$ pregnancy rate.

During the breeding season, cows submitted to NP and NPSu managements lost 0.99 and 1.05 body condition score, respectively, due to the increase in nutritional requirements during lactation (NRC, 1996; Freetly, 1999) and quality reduction of natural pastures (Table 2). Forage mass was not limiting, but the expected benefits of slashing natural pastures, which was carried out in November 2007, were not obtained due to the long drought that happened during the following months $(52,42$, and $53 \mathrm{~mm}$, in November and December, 2007 and January, 2008, respectively; Table 1), hindering pasture resprouting. This has probably caused intake reduction, consequently impairing reproductive performance. At the end of the breeding season, the cows maintained on natural pastures during the pre-calving period (NP and NPSu) presented an average difference of -0.47 body condition score $(4.23-3.77)$ as compared to those kept on improved pastures, resulting in worse reproductive performance. These results indicate

Table 4 - Body weight $(\mathrm{kg})$ and body condition score in the beginning and end of the breeding season and cow pregnancy rate according to feeding management practice

\begin{tabular}{|c|c|c|c|c|}
\hline Parameter & $\begin{array}{c}\text { Natural } \\
\text { pastures }\end{array}$ & $\begin{array}{l}\text { Natural pastures } \\
\text { with protein } \\
\text { supplementation } \\
\text { as yearlings }\end{array}$ & $\begin{array}{c}\text { Natural pastures as yearlings } \\
\text { and improved } \\
\text { pastures } \\
\text { post-calving }\end{array}$ & $\begin{array}{l}\text { Natural pastures with } \\
\text { protein supplementation } \\
\text { as yearlings and improved } \\
\text { pastures post-calving }\end{array}$ \\
\hline \multicolumn{5}{|c|}{ Body weight during the breeding season } \\
\hline Initial (November $15^{\text {th }} 2007$ ) & 451 & 471 & 455 & 459 \\
\hline Final (January $30^{\text {th }} 2008$ ) & $412 b$ & $426 \mathrm{ab}$ & $440 \mathrm{ab}$ & $449 \mathrm{a}$ \\
\hline \multicolumn{5}{|l|}{ Body condition score } \\
\hline Initial & 4.77 & 4.80 & 4.71 & 4.65 \\
\hline Final & $3.78 b$ & $3.75 b$ & $4.15 \mathrm{a}$ & $4.31 \mathrm{a}$ \\
\hline Mean daily weight variation & $-0.082 b$ & $-0.136 a$ & $-0.031 c$ & $-0.066 b c$ \\
\hline Pregnancy (\%) & $76.5 \mathrm{~B}$ & $71.4 \mathrm{~B}$ & $94.7 \mathrm{~A}$ & $95.0 \mathrm{~A}$ \\
\hline
\end{tabular}

a, b Means followed by different letters in the same row differ $(\mathrm{P}<0.05)$ by Tukey test.

A, B Means followed by different letters in the same row differ $(\mathrm{P}<0.01)$ by Chi-square test. 
that both forage allowance (Simeone \& Lobato, 1996; Fagundes et al., 2003) and quality during the breeding season are determinant factors of body condition score at the end of breeding season and reproductive performance (Nicol \& Nicoll, 1987). Barcellos \& Lobato (1997) found 47.3 and $80.5 \%$ increase in the pregnancy rate of cows with 3 and 5 body condition scores, respectively, relative to body condition score 1 .

When pregnancy rates were compared among treatments, as determined by ultrasound examination carried out seven and 48 days after the end of the breeding season, only a $10.5 \%$ increase in pregnancy rate was observed (from $73.9 \%$ to $84.4 \%$ ) (Table 5 ). Whereas cows on improved natural pastures conceived on the first 50 days of the breeding season, $18.4 \%$ of the cows grazing on natural pastures conceived in the last 20 days of that season.

The first pregnancy diagnosis made after the breeding season showed that cows maintained on improved natural pastures first conceived during the post-calving period (Table 5), demonstrating the better quality of improved pastures in the beginning of the breeding season, promoting better performance during this stage. The lower body weight and body condition score at end of the breeding season (Table 4 ) resulted in an average pregnancy rate of $74 \%$ in cows managed on NP and NPSu. Despite being lower than the body weights and body condition scores obtained in treatments INP and INPSu, these are considered acceptable in commercial herds after the long drought period that occurred during the breeding season. These pregnancy rates also result from acceptable body weight and body condition score at calving (Table 3 ) and beginning of the breeding season (Table 4), and were not statistically different from those obtained at the same moments with INP and INPSu management practices. Those rates are also much higher than those reported in other studies (Gottschall \& Lobato 1996; Simeone \& Lobato, 1996; Fagundes et al., 2003).

Despite the lack of difference $(\mathrm{P}>0.05)$ in body weight and body condition score at calving and at the beginning of the breeding season between pregnant and non-pregnant cows (Table 6), those that did not conceive presented higher weight loss until the end of the breeding season, leading to lower body weights and body condition scores at the end of the breeding season $(\mathrm{P}<0.05)$. Lobato et al. (1998a) also found lower pregnancy rates in first-calf cows presenting higher body weight at the end of the breeding season. According to Pilau \& Lobato (2009), the higher body weight associated to the higher body condition score determined pregnancy rate and conception period in the second breeding season of first-calf cows.

Body weight of first-calf cows at the end of the breeding season ranged from 339 to $532 \mathrm{~kg}$, and $70 \%$ weighed from 409 to $532 \mathrm{~kg}$ at the end of the breeding season. These results are in agreement to Rovira (1996), who suggests that first-calf cows should weigh $420 \mathrm{~kg}$ at the end of the breeding season in herds with $500 \mathrm{~kg}$ mature body weight. In addition, they evidence that there is weight variation among individuals within the same animal class and within a herd, which is typical of a developing production system, as well as the genetic capacity of cows conceiving even with body weights lower (Deese \& Koger, 1967)

Table 5 - Pregnancy rate (\%) as a function of feeding management practices

\begin{tabular}{lcccc}
\hline Parameter & $\begin{array}{c}\text { Natural } \\
\text { pastures }\end{array}$ & $\begin{array}{c}\text { Natural pastures } \\
\text { with protein } \\
\text { supplementation } \\
\text { as yearlings }\end{array}$ & $\begin{array}{c}\text { Natural pastures as yearlings } \\
\text { and improved } \\
\text { pastures } \\
\text { post-calving }\end{array}$ & $\begin{array}{c}\text { Natural pastures with } \\
\text { protein supplementation } \\
\text { of yearlings and improved } \\
\text { pastures post-calving }\end{array}$ \\
\hline $\begin{array}{l}\text { Pregnancy diagnosis date } \\
\text { February } 7^{\text {th }} 2008\end{array}$ & $58.8 \mathrm{C}$ & $52.4 \mathrm{C}$ & & $\begin{array}{c}\text { Means } \\
\text { March 17 }\end{array} 7^{\text {th }} 2008$ \\
\hline
\end{tabular}

A, B Means followed by different letters in the same row differ $(\mathrm{P}<0.01)$ by Chi-square test.

Table 6 - Cow body weight (BW) and body condition score (BCS) in the beginning and end of the breeding season according to physiological status

\begin{tabular}{lcc}
\hline Parameters & Pregnant & Non-pregnant \\
\hline Body weight at calving (kg) & 428 & 430 \\
Body condition score at calving & 3.54 & 3.45 \\
Body weight - beginning of the breeding season (kg) & 462 & 453 \\
Body condition score - beginning of the breeding season & 4.74 & 4.70 \\
Body weight - end of the breeding season (kg) & $440 \mathrm{a}$ & $413 \mathrm{~b}$ \\
Body condition score - end of the breeding season & $4.14 \mathrm{a}$ & $3.66 \mathrm{~b}$ \\
\hline
\end{tabular}

$\mathrm{a}, \mathrm{b}$ Means followed by different letters in the same row differ $(\mathrm{P}<0.05)$ by Tukey test. 
than those recommended in recent studies (Rovira, 1996; Lobato et al., 1998a,b; Pötter \& Lobato, 2004).

The number of non-pregnant cows grazing on natural pastures was higher when compared to the other treatments inasmuch as cows presented low body weight and body condition score at the end of the breeding season. According to Ciccioli et al. (2003), these factors significantly contribute to reduce pregnancy rates.

The observed variations in body weight and body condition score observed in all cows in the present study are explained by the variation in the quality both of natural and improved natural pastures (Table 2), which was related to the drought that started in September, 2007, and that was aggravated from November 2007 to January 2008 (Table 1). These results indicate the influence of other factors, besides forage allowance, on cow response. Rainfall regime and high environmental temperature may have affected the results and should be taken into account when they are being interpreted. Considering the historic climate data of Quaraí, Rio Grande do Sul, and weather variation during the experimental period, the results of the present study clearly show that forage supply was not the only factor affecting cow response. Total precipitation from November 2007 to January, 2008 (147 mm) was below the historical average of the region, affecting forage quality. In addition, the higher average maximum temperatures $\left(32^{\circ} \mathrm{C}\right)$ (FEPAGRO, 2008; Table 1), probably changed ingestive behaviors, reducing intake and negatively influencing the reproductive performance (Zakari et al., 1981) of cows maintained on natural pastures.

Supplementing yearlings with proteinated salt did not influence pregnancy rates (Tables 4 and 5) of first-calf cows during the first breeding season ( $83.2 \%$ vs. $86.6 \%$; Tanure, 2008). This is consistent with the findings of Ferrell (1982) and Van Niekerk et al. (1990), who also did not find any effects of pre-breeding nutritional management of heifers on their pregnancy rates as first-calf cows.

The results obtained in the present study show adequate reproductive performance of first-calf cows at 36 months of age maintained on natural pastures, and significantly better performance of those managed on natural pastures which improved with the introduction of better quality species. Adequate pasture allowances during the entire experimental period, despite severe drought, allowed the cows maintained on natural pastures to achieve higher reproductive indexes when compared to the average performance obtained in the state of Rio Grande do Sul. This demonstrates the importance of providing adequate pasture allowance by reducing stocking density during fall-winter, post-calving period, and breeding season (Quadros \& Lobato, 1996; Simeone \& Lobato, 1996; Fagundes et al., 2003). Therefore, the better reproductive performance obtained with stocking rates equal or lower to those used in the present study show that the stocking rate of $0.8 \mathrm{AU} / \mathrm{ha}$ (360 kg BW/ha) during the 12 months of the year required by the Instituto Nacional de Colonização e Reforma Agrária (INCRA) is completely inadequate. It is believed that the required stocking rate of $0.8 \mathrm{AU} /$ ha has limited pasture allowance of breeding herds, thereby continuously hindering the improvement of reproductive indexes of herds managed on the highly diverse soil types of the state of Rio Grande do Sul (EMBRAPA, 1999).

The better nutritional supply provided by improved natural pastures during the post-calving period promoted high pregnancy rates in the following breeding season, which is consistent with the results previously obtained by Lobato et al. (1998a,b), Lobato et al. (2000), Pötter \& Lobato (2004) and Lobato et al. (2010).

\section{Conclusions}

The supply of proteinated salt to yearling heifers before the first breeding season does not affect the reproductive performance of first-calf cows. The use of natural pastures with stocking rates according to adequate pasture allowance during the pre-calving period allows the maintenance of first-calf cow body weight and body condition score during gestation, resulting in adequate body weight and body condition score at calving. Cows managed on improved natural pastures during the post-calving period present higher body weight and body condition score, higher pregnancy rate, and conceive earlier when compared to those managed exclusively on natural pastures. Body weight and body condition score difference at the end of the breeding season are determinant for pregnancy rates.

\section{Acknowledgements}

The authors thank the owners and workers of Agropecuária Caty for their incentive and for allowing us to carry out this experiment.

\section{References}

ASSOCIATION OF OFICIAL ANALYTICAL CHEMIST - AOAC Official methods of analysis. 12.ed. Washington, D.C., 1975. $1094 \mathrm{p}$.

BARCELLOS, J.O.J.; LOBATO, J.F.P. Desempenho reprodutivo de vacas primíparas Hereford e mestiças Nelore-Hereford com estação de parição e monta no outono/inverno ou primavera/ 
verão. I. Taxa de Prenhez. Revista Brasileira de Zootecnia, v.26, n.5, p.976-985, 1997.

BERETTA, V.; LOBATO, J.F.P.; Mielitz NETTO, C.G.A. Produtividade e eficiência biológica de sistemas pecuários diferindo na idade das novilhas ao primeiro parto e na taxa de natalidade do rebanho do Rio Grande do Sul. Revista Brasileira de Zootecnia, v.30, n.4, p.1278-1286, 2001

BOLDRINI, I.I. Campos do Rio Grande do Sul: caracterização fisonômica e problemática ocupacional. Porto Alegre: UFRGS. Boletim do Instituto de Biociências, 1997. 39p. (Publicação, 56).

CACHAPUZ, J.M.S.; LOBATO, J.F.P.; LEBOUTE, E.M. Pastagens melhoradas e suplementos alimentares no comportamento reprodutivo de novilhas de primeira cria. Pesquisa Agropecuária Brasileira, v.25, n.3, p.445-454, 1990.

CICCIOLI, N.H.; WETTEMANN, R.P.; SPICER, L.J. et al. Influence of body condition at calving and postpartum nutrition on endocrine function and reproductive performance of primiparous beef cows. Journal of Animal Science, v.81, n.12, p.3107-3120, 2003.

DEESE, R.E.; KOGER, M. Heritability of reproduction. In: CUNHA, T.J.; WARNICK, A.C.; KOGER, M. (Eds.) Factors affecting calf crop. Gainesville: University of Florida Press, 1967. p.232-238.

DeROUEN, S.M.; FRANKE, D.E.; MORRISON, D.G. et al. Prepartum body condition and weight influences on reproductive performance of first-calf beef cows. Journal of Animal Science, v.72, n.5, p.1119-1125, 1994.

DZIUK, P.J.; BELLOWS, R.A. Management of reproduction on beef cattle, sheep and pigs. Journal of Animal Science, v.57, p.355-379, 1983 (suppl. 2).

EMPRESA BRASILEIRA DE PESQUISA E AGROPECUÁRIA EMBRAPA. Centro Nacional de Pesquisa de Solos. Sistema brasileiro de classificação de solos. Rio de Janeiro: EMBRAPA Solos, 1999. 412p.

FAGUNDES, J.I.B.; LOBATO, J.P.L.; SCHENKEL, F.S. Efeito de duas cargas animais em campo nativo e de duas idades a desmama no desempenho de vacas de corte primíparas. Revista Brasileira de Zootecnia, v.32, n.6, p.1722-1731, 2003 (supl. 1)

FERRELL, C.L. Effects of postweaning rate of gain on onset of puberty and productive performance of heifers of different breeds. Journal of Animal Science, v.55, n.6, p.1272-1283, 1982.

FREETLY, H.C. The replacement heifer and the primiparous cow. In: REUNIÃO ANUAL DA SOCIEDADE BRASILEIRA DE ZOOTECNIA, 36., 1999, Porto Alegre. Anais... Porto Alegre: SBZ, 1999. p.241-247.

FUNDAÇÃO ESTADUAL DE PESQUISA AGROPECUÁRIA FEPAGRO [2008]. Dado metereológico por elemento: diário (Laboratório de Meteorologia). Disponível em: <http:// www.fepagro.rs.gov.br/index.php? acao $=$ publ_ele \& cod_cat_publicacao $=11 \& p a g=4 \#>$ Acesso em: 10/1/2009.

GIBB, M.J.; TREACHER, T.T. The effect of herbage allowance on herbage intake and performance of lambs grazing perennial ryegrass and red clover swards. Journal of Agricultural Science, v.86, p.355-365, 1976.

GOTTSCHALL, C.S.; LOBATO, J.F.L. Comportamento reprodutivo de vacas de corte primíparas submetidas a três lotações em campo nativo. Revista Brasileira de Zootecnia, v.25, n.1, p.46-57, 1996

HAYDOCK, K.P.; SHAW, N.H. The comparative yield method for estimating dry matter yield of pasture. Australian Journal of Experimental Agriculture and Animal Husbandry, v.15, n. 1, p.663-670, 1975 .

HERD, D.H.; SPROTT, L.R. Body condition, nutrition and reproduction of beef cows. [S.I]: The Texas A\&M University System, 1996. Texas Agricultural Extension Service. 11p. (reprint).

LOBATO, J.F.P.; DERESZ, F.; LEBOUTE, E.M. et al. Pastagens melhoradas e suplementação alimentar no comportamento reprodutivo de vacas de corte primíparas. Revista Brasileira de Zootecnia, v.27, n.1, p.47-53, 1998a

LOBATO, J.F.P.; MENEGAZ, A.; PEREIRA, A.C.G. Sistemas forrageiros pré e pós-parto e o desempenho reprodutivo de vacas primíparas. Revista Brasileira de Zootecnia, v.39, n.9, p.2081-2090, 2010

LOBATO, J.F.P.; MÜLLER, A.; PEREIRA NETO, O.A. et al. Efeitos da idade à desmama dos bezerros sobre o desempenho reprodutivo de vacas de corte primíparas. Revista Brasileira de Zootecnia, v.29, n.6, p.2013-2018, 2000 (supl. 1).

LOBATO, J.F.P.; ZANOTTA JÚNIOR, R.L.D.; PEREIRA NETO, O.A. Efeitos das dietas pré e pós-parto na eficiência reprodutiva de vacas primíparas de corte. Revista Brasileira de Zootecnia, v.27, n.5, p.857-862, 1998b.

LOWMAN, B.G.; SCOTT, N.; SOMERVILlE, S. Condition scoring beef cattle. Edinburgh: East of Scotland College of Agriculture, 1973. 8p. (Bulletin, 6).

MERTENS, D.R. Predicting intake and digestibility using mathematical models of ruminal function. Journal of Animal Science, v.64, n.5, p.1548-1558, 1987

MORAES, A.; MARASCHIN, G.E.; NABINGER, C. Pastagens nos ecossistemas de clima subtropical: pesquisas para o desenvolvimento sustentável. In: ANDRADE, R.P.; BARCELLOS, A.O.; ROCHA, C.M.C. (Eds.) SIMPÓSIO SOBRE PASTAGENS NOS ECOSSISTEMAS BRASILEIROS, 1995, Brasília. Simpósio... Brasília: SBZ, 1995. p.147-200.

MORAES, A.A.S.; LOBATO, J.F.P. Efeito de duas épocas de desmama no desempenho reprodutivo de vacas de corte. Revista Brasileira de Zootecnia, v.22, n.6, p.1003-1011, 1993.

MORENO, J.A. Clima do Rio Grande do Sul. Porto Alegre: Secretaria da Agricultura, 1961. 41p.

NATIONAL RESEARCH COUNCIL - NRC. Nutrient requirements of beef cattle. 7.ed. Washington, D.C.: National Academy Press, 1996. 242p.

NICOL, A.M.; NICOLL, G.B. Pastures for beef cattle. In: NICOL, A.M. (Ed.) Feeding livestock on pasture. Lincoln: New Zealand Society of Animal Production, 1987. p.119-131.

PILAU, A.; LOBATO, J.F.P. Desenvolvimento e desempenho reprodutivo de vacas primíparas aos $22 / 24$ meses de idade. Revista Brasileira de Zootecnia, v.38, n.4, p.728-736, 2009.

PINTO, C.E.; CARVALHO, P.C.F.; FRIZZO, A. et al. Comportamento ingestivo de novilhos em pastagem nativa no Rio Grande do Sul. Revista Brasileira de Zootecnia, v.36, n.2, p.319-327, 2007.

PÖTTER, B.A.A.; LOBATO, J.F.P. Efeitos de carga animal, pastagem melhorada e da idade de desmame sobre o comportamento reprodutivo de vacas primíparas. Revista Brasileira de Zootecnia, v.33, n.1, p.192-202, 2004.

PÖTTER, L.; LOBATO, J.F.P.; MIELITZ NETTO, C.G.A. Produtividade de um modelo de produção para novilhas de corte primíparas aos dois, três e quatro anos de idade. Revista Brasileira de Zootecnia, v.27, n.3, p.613-619, 1998

QUADROS, S.A.F.; LOBATO, J.F.P. Efeitos da lotação no comportamento reprodutivo de vacas de corte primíparas. Revista Brasileira de Zootecnia, v.25, n.1, p.22-35, 1996.

ROSADO JÚNIOR, A.G.; LOBATO, J.F.P. Application of a model of management by macroprocess to a beef cattle enterprise: a case study. Revista Brasileira de Zootecnia, v.38, n.11, p.2280-2288, 2009

ROVIRA, J. Manejo nutritivo de los rodeos de cría en pastoreo Montevideo: Hemisferio Sur, 1996. 288p.

SIMEONE, A.; LOBATO, J.F.P. Efeitos da lotação animal em campo nativo e do controle da amamentação no comportamento reprodutivo de vacas de corte primíparas. Revista Brasileira de Zootecnia, v.25, n.6, p.1217-1227, 1996.

SPITZER, J.C. Influences of nutrition on reproduction in beef cattle. In: MORROW, D.A. (Ed.) Current therapy in theriogenology 2.ed. Philadelphia: W.B. SAUNDERS, 1986. p.320-341. 
SPITZER, J.C.; MORRISON, D.G.; WETTEMANN, R.P. et al. Reproductive responses and calf birth and weaning weights as affected by body condition at parturition and postpartum weight gain in primiparous beef cows. Journal of Animal Science, v.73, n.5, p.1251-1257, 1995.

STATGRAPHICS. User's manual version 4.1 for windows. [S.I.]: Statistical Graphics Corporation, 1999.

TANURE, S. Estratégias de manejo nutricional para novilhas e vacas primíparas de corte. 2008. 139f. Dissertação (Mestrado em Zootecnia) - Universidade Federal do Rio Grande do Sul, Porto Alegre, 2008.

VAN NIEKERK, A.; KERNICK, R.; LISHMAN, A.W. The effect of winter and summer nutricional levels on the reproductive performance of beef heifers bred at 2 years of age. Animal Production, v.51, p.255-262, 1990.
VAN SOEST, P.J. Nutritional ecology of ruminant. 2.ed. New York: Cornell University Press, 1994. 476p.

VAZ, R.Z.; LOBATO, J.F.P.; RESTLE, J. Influence of weaning age on the reproductive efficiency of primiparous cows. Revista Brasileira de Zootecnia, v.39, n.2, p.299-307, 2010 .

VIEIRA, A.; LOBATO, J.F.P.; CORRÊA, E.S. et al. Produtividade e eficiência de vacas Nelore em pastagem de Brachiaria decumbens Stapf nos cerrados do Brasil central. Revista Brasileira de Zootecnia, v.3, n.4, p.1357-1365, 2005.

WILTBANK, J.N.; ROWDEN, W.W.; INGALLS, J.E. et al. Effect of energy level on reproductive phenomena of mature Hereford cows. Journal of Animal Science, v.21, n.2, p.219-225, 1962.

ZAKARI, A.Y.; MOLOKWIN, E.C.I.; OSORI, D.I.K. Effects of rectal and ambient temperatures and humidity on conception rates. Theriogenology, v.16, n.3, p.331-336, 1981. 